\title{
Analiza procesu utowarowienia edukacji z wyszczególnieniem szkolnictwa wyższego
}

\author{
ANITA POKUSIŃSKA ${ }^{1}$ \\ ${ }^{1}$ Uniwersytet im. Adama Mickiewicza w Poznaniu, Wydział Prawa i Administracji, al. Niepodległości 53, \\ 61-714 Poznań. ORCID: https://orcid.org/0000-0002-0172-003X, Email: a.pokusinska@op.pl
}

STRESZCZENIE: Analiza procesu utowarowienia edukacji z wyszczególnieniem szkolnictwa wyższego stanowiła temat artykułu, którego celem było wyjaśnienie tego zjawiska i jego dokładny opis. Zakres artykułu został ograniczony do edukacji wyższej z uwagi na obszerność poruszanych zagadnień. Głównym problemem badawczym było znalezienie odpowiedzi na pytanie, w jakim stopniu, i w jaki sposób utowarowienie edukacji wpływa na szanse kształcenia młodych ludzi. Charakterystyka zjawiska uwzględniła problemy dotyczące konsekwencji procesu komodyfikacji i jego elementów. Kolejne części opracowania zawierają w sobie wyjaśnienie istoty zjawiska, kluczowe pojęcia oraz kontekst pojawienia się utowarowienia w obszarze edukacji. Istotnym było również zwrócenie uwagi na proces odwrotny, czyli dekomodyfikację. Wyszczególniono formy, jakie przyjmuje odtowarowienie edukacji oraz ich wady i zalety. Analizie poddano także następstwa procesu komodyfikacji i dekomodyfikacji, do których zaliczono między innymi obniżanie wartości dyplomów. By wyjaśnić cel i problemy badawcze, wykorzystano wtórną analizę danych, na którą składała się literatura, prace naukowe oraz raporty, między innymi Głównego Urzędu Statystycznego i Eurostatu. Analiza obejmowała raporty i dane dotyczące Polski, jak również innych krajów europejskich, co umożliwiło porównywanie istotnych aspektów procesu utowarowienia edukacji między krajami oraz nakreślenie sytuacji uniwersytetów w Europie. Bazując na analizie danych zastanych, wyróżniono najważniejsze konsekwencje procesu utowarowienia w zakresie szkolnictwa wyższego, do których zaliczono wzrost zróżnicowania wśród społeczeństwa, rosnącą liczbę osób z wykształceniem wyższym, powstawanie alternatywnych form umożliwiających zdobycie wspomnianego wykształcenia, jak również przekształcenie wiedzy akademickiej w wiedzę przyjmującą formę towaru. Proces utowarowienia edukacji wyższej bez wątpienia jest zauważalny na uniwersytetach, co zostało udokumentowane w pracy za pomocą opisu jego poszczególnych 
elementów i konsekwencji.

SŁOWA KLUCZOWE: utowarowienie, komodyfikacja, szkolnictwo wyższe, dekomodyfikacja, przemoc symboliczna

\section{WPROWADZENIE}

Utowarowienie edukacji jest zjawiskiem, które ujawniło się szczególnie podczas odbudowy gospodarek państw po wszelkich kryzysach gospodarczych czy tych związanych z wojną. Proces ten jest wyjątkowo istotny współcześnie z uwagi na jego liczne konsekwencje dla osób uczących się, jak i pracowników naukowych. Celem badań było wyjaśnienie zjawiska utowarowienia w kontekście szkolnictwa i edukacji wyższej, jak również opis tego procesu. Głównym problemem badawczym była próba odpowiedzi na pytanie, w jakim stopniu, i w jaki sposób utowarowienie edukacji wpływa na szanse kształcenia młodych ludzi. W tym kontekście równie ważne były konsekwencje tego procesu i określenie jego elementów.

Przedmiotem badań został więc proces utowarowienia edukacji. Przyjętą perspektywą teoretyczną - koncepcja przemocy symbolicznej Pierre’a Bourdieu, której istota polega na legitymizowaniu, wzmacnianiu i utrwalaniu przemocy dzięki symbolicznym środkom (Bourdieu i Passeron 1990: 17). Ważne są dwa aspekty tej koncepcji - kształtowanie habitusu jednostek oraz mechanizmy i szanse awansu szkolnego (Bourdieu i Passeron 1990: 17). Należy zwrócić uwagę także na to, że przynależność do klasy pochodzenia i kapitał społeczno-kulturowy są czynnikami, które w sposób znaczący wpływają na to, w jaki sposób przebiega edukacja jednostki (Bourdieu i Passeron 1990: 18).

Agnieszka Suchocka rekonstruuje stanowisko Bourdieu i podsumowuje, czym jest przemoc symboliczna: „Przemoc symboliczna jest dyskretną formą manipulacji, jest odmianą panowania ukrytego, zawoalowanego. Poprzez działania, których podtekstu osoby zdominowane nie potrafią odczytać, jednostki dominujące przekazują im treści, które w danej kulturze uważane są za jedyne prawdziwe, za słuszną drogę" (Suchocka 2011: 295). Przemoc symboliczna pojawia się więc już na pierwszych szczeblach edukacji, gdzie u podstaw działań pedagogicznych leży „narzucanie i wdrażanie arbitralności kulturowej” (Suchocka 2011: 295). Kolejnym elementem przemocy symbolicznej, która pojawia się w edukacji jest system zdobywania ocen, gdzie uczniowie i studenci są oceniani przez pryzmat wszelkich wyników egzaminacyjnych i testowych, co skutkuje kategoryzowaniem uczniów i studentów na grupy 'lepsze’ i 'gorsze' (Suchocka 2011: 295). W kontekście utowarowienia edukacji, szczególnie wyższej, przemoc symboliczna przejawia się na przykład w sytuacji, kiedy studenci inwestują swój kapitał ekonomiczny w zamian za otrzymanie ocen, a następnie - tytułów naukowych. Z założenia, o którym wspomina Suchocka, szkoła, a w przypadku tej pracy także uniwersytet, powinny być miejscami, gdzie nie występują znaczące różnice pomiędzy uczniami czy studentami. Jednakże, jak zauważa badaczka, status majątkowy przyczynia się do stygmatyzacji lub wykluczenia (w przypadku niedoboru kapitału ekonomicznego), szczególnie w momencie wyboru instytucji kształcenia czy w przypadku 
przejawianych motywacji w zdobywaniu wykształcenia.

Dzięki wtórnej analizie danych udało się odnaleźć odpowiedzi na postawione pytania badawcze. Wykorzystano badania przeprowadzone zarówno przez CBOS, GUS jak i Eurostat. Klucz doboru poszczególnych baz danych nie był jasno sprecyzowany. Po przeprowadzeniu rozeznania w badaniach powiązanych z tematem, wybrano te, które najbardziej przyczyniały się do znalezienia odpowiedzi na pytania badawcze postawione na początku pracy.

\section{WNIOSKI Z ANALIZY DANYCH ZASTANYCH}

\section{DANE O POLSCE I KRAJACH EUROPEJSKICH W KONTEKŚCIE UNIWERSYTETÓW}

Według danych pochodzących z Głównego Urzędu Statystycznego w Polsce w roku akademickim 2016/2017 studiowało na uczelniach wyższych w sumie 1348822 osób. Edukację na poziomie wyższym wybierają zdecydowanie częściej kobiety niż mężczyźni. W tym samym roku uczelnie wyższe ogółem wśród studentów liczyły 776464 kobiet. Tendencja, jeżeli chodzi o osoby podejmujące studia na uczelni wyższej, jest malejąca. Na spadającą liczbę studentów ma wpływ niż demograficzny. Niska liczba zawieranych małżeństw oraz zmiany w dzietności w Polsce mają negatywny wpływ na liczbę urodzeń. Dodatkowo zjawisko to pogłębia się przez wzmożoną emigrację, szczególnie młodych ludzi (GUS 2019: 10). Wśród studentów w roku 2016/2017 dominowały uczelnie publiczne - do tych uczęszczało 1034161 osób. Z uczelni prywatnych korzystało 314661 osób (GUS 2017: 29).

Uczelnie wyższe mogą różnić się w poszczególnych krajach pod względem orientacji akademickiej lub zawodowej, statusu prywatnego lub publicznego, dofinansowania lub jego braku (Eurostat 2012: 22) W większości krajów z Europejskiego Obszaru Szkolnictwa Wyższego istnieją uczelnie publiczne jak i prywatne jednocześnie. Tylko w sześciu spośród wszystkich państw objętych raportem, uczelnie mają charakter wyłącznie publiczny. Są to Andora, Belgia, Dania, Finlandia, Grecja i Włochy (Eurostat 2012: 22).

Dane Eurostatu wskazują na silną zależność pomiędzy chęcią zdobycia wyższego wykształcenia a wykształceniem rodziców studenta. W prawie wszystkich krajach europejskich, których dane zostały wykorzystane do stworzenia raportu, szanse zdobycia wyższego wykształcenia są zależne od wykształcenia, jakie posiadają rodzice (Eurostat 2012: 78). W krajach takich, jak Dania, Słowacja i Szwecja związek ten jest jednak dosyć słaby. Dużo większe szanse na ukończenie uczelni wyższej mają dzieci rodziców z wyższym wykształceniem - jest to od 2 do 5 razy bardziej prawdopodobne niż w przypadku rodziców ze średnim wykształceniem. Największy związek między tymi dwoma czynnikami w 2008 roku dostrzegalny był w Rumunii i na Słowacji (Eurostat 2012: 78).

Oprócz tradycyjnych form umożliwiających rozpoczęcie edukacji wyższej, można wyróżnić też alternatywne sposoby na zyskanie wykształcenia w Europejskim Obszarze Szkolnictwa Wyższego. Raport Eurostatu wyróżnia dwie klasyfikacje: kraje, w któ- 
rych istnieją alternatywy zdobycia wyższego wykształcenia oraz kraje, gdzie pozostaje tylko jeden sposób ukończenia studiów (Eurostat 2012: 83). Spośród 47 państw objętych raportem, w 22 są ustanowione alternatywne ścieżki zdobycia wykształcenia. W pozostałych 25 systemach edukacyjnych państw tylko dzięki dyplomowi ukończenia szkoły średniej można kontynuować naukę na uczelni wyższej (Eurostat 2012: 84). Alternatywne sposoby na rozpoczęcie nauki na wyższym poziomie w różnych krajach i systemach mogą przybierać rozmaite formy. „Niestandardowi” uczniowie najczęściej korzystają z dodatkowych umiejętności nabytych poza formalnymi ramami uczenia się, na przykład wolontariat czy doświadczenie zawodowe (Eurostat 2012: 84). Uprawnieniami do rozpoczęcia studiów mogą być również specjalne programy przygotowawcze, które przygotowują kandydata na „wejście” w edukację wyższą (Eurostat 2012: 85).

Eurostat zaprezentował rozpowszechnienie opłat w różnych państwach w pierwszym cyklu edukacji wyższej, nie wyszczególniając, czego dokładnie dotyczą wydatki. Opłaty związane z podjęciem studiów są pobierane w większości europejskich państw. Skandynawskie kraje wyróżniają się na tym tle, ponieważ nie obciążają studentów żadnymi kosztami w przytoczonym cyklu nauki (Eurostat 2012: 91). Taki model ma związek z geograficznym położeniem i aspektem kulturowym. W ponad połowie państw Europejskiego Obszaru Szkolnictwa Wyższego część studentów zobowiązana jest do uiszczania opłat związanych z edukacją (Eurostat 2012: 91). Oznacza to, że istnieją kryteria, które regulują te wydatki i wyraźnie wskazują na to, kto, oraz w jakim przypadku, zobowiązany jest do uiszczania opłat. W 14 krajach wyszczególnionych w raporcie do ponoszenia kosztów zobowiązani są wszyscy studenci. Polska należy do grupy państw, gdzie finansowe obciążenie dotyczy części, a nie wszystkich studentów. Ciekawym przypadkiem w tym kontekście są Czechy - tam pobierane są od każdego studenta jedynie opłaty rejestracyjne, co w porównaniu z innymi krajami z tej grupy jest opłatą bardzo niską (Eurostat 2012: 91). Wszyscy (lub prawie wszyscy) studenci są zobowiązani płacić z uwagi na wyższą edukację w krajach takich, jak Włochy, Holandia, Portugalia, Szwajcaria, Wielka Brytania. Brak opłat dotyczy krajów nordyckich oraz Malty i Austrii, które posiadają bardzo niski ogólny odsetek płatników (Eurostat 2012: 91).

\section{WARTOŚĆ DYPLOMÓW I ICH KONKURENCYJNOŚĆ NA RYNKU PRACY}

Należy wspomnieć o umasowieniu szkolnictwa wyższego i przywołać dane, na które powołuje się także Marta Opiłowska w swoim artykule. W 1990 roku w Polsce studiowało około 400000 studentów, już w 2009 liczba ta sięgała 2000000 osób (Opiłowska 2009: 107). Jak wskazuje autorka, tak wysoki przyrost był wynikiem powstania kilkuset prywatnych szkół, w których można było zdobyć tytuły magistra i licencjata. Uczelnie prywatne w większości kształcą w zakresie kierunków społecznych i ekonomicznych, dlatego w artykule można przeczytać o „nadprodukcji absolwentów” (Opiłowska 2009: 107). Nierówność, jaka powstaje na rynku pracy w związku z dysproporcją w zakresie absolwentów uczelni wyższych kierunków społecznych, ekonomicznych w stosunku do specjalistów nauk ścisłych i niedopasowaniem do potrzeb rynku, skutkuje trudno- 
ściami na rynku pracy, z którymi mogą się spotkać studenci z „nadprodukcji” (Opiłowska 2009: 108).

Marta Opiłowska powołuje się na koncepcję Collinsa, gdzie kluczową tezą jest inflacja kredencjałów, czyli w przypadku edukacji wyższej właśnie dyplomów. W tym kontekście dobra, które są w nadmiarze produkowane, dotyka inflacja, a w przypadku uniwersytetów są to tytuły licencjata i magistra (Opiłowska 2009: 112). Sytuacji zdobycia odpowiedniego wykształcenia towarzyszą inwestycje pieniężne, zarówno jeśli chodzi o płatności takie jak czesne w przypadku szkół prywatnych, jak również koszty związane z samym studiowaniem (materiały, zamieszkanie i tym podobne). Dodatkowe koszty, jakie pojawiają się podczas studiowania na uczelniach publicznych, które z założenia są bezpłatne, są narzędziem przemocy symbolicznej, o której pisze Bourdieu (Bourdieu, Wacquant 2001). Zdawałoby się, że inwestycja w wykształcenie powinna się „zwrócić” w formie wartościowego dyplomu, świadczącego o kwalifikacjach absolwenta szkoły wyższej. Sytuacja urynkowienia uniwersytetu i powszechność dyplomów powoduje sytuacje, w których większą wartość nabywają alternatywne sposoby uzyskania wiedzy, umiejętności czy kwalifikacji zawodowych (Opiłowska 2009: 112). Utowarowienie w zakresie szkolnictwa wyższego, jak wynika z powyższej analizy, dotyczy zarówno zdobywania wykształcenia wyższego przez studiowanie na uczelni, jak również inwestowania w dodatkowe, szeroko rozumiane kursy dokształcające pozwalające na stanie się bardziej konkurencyjnym na rynku pracy, co tym samym może podnosić wartość zdobytych umiejętności i wykształcenia.

Koncepcja kredencjalizmu i teoria gier, o której pisze Opiłowska, pokazuje, że ostatnimi czasy wartość otrzymanego dyplomu świadczącego o wykształceniu wyższym zdecydowanie zmalała (Opiłowska 2009: 116). Inflacja dyplomu, która również została wspomniana w przytaczanym artykule, wymusza na studentach szukania sposobów na wyróżnienie się pod kątem wykształcenia na rynku pracy. Jest to rodzaj przemocy symbolicznej definiowanej przed Bourdieu jako „forma przemocy, która oddziałuje na podmiot społeczny przy jego współudziale” (Bourdieu, Wacquant 2001: 162). Ważnym elementem tej teorii jest nierozpoznanie - przemoc występuje tam, gdzie nie jest za nią uznawana. Trudno więc nazwać sytuację studentów jako dosłowną przemoc skierowaną wobec nich przez uczelnie, które masowo „produkują” absolwentów, czy jako przemoc stosowaną przez rynek pracy. Uniwersytet jest natomiast miejscem, gdzie w takiej sytuacji występuje przemoc symboliczna, występuje ona w miejscu, gdzie nie uważa się jej za przemoc (Bourdieu, Wacquant 2001: 161).

Nawiązując do stanowiska Marty Opiłowskiej, należy rozważyć istotność oraz wartość dyplomów ukończenia studiów. Zdaniem Damona Clarka i Paco Martorella wiele wskazuje na to, że certyfikat o zakończeniu kształcenia na uczelni wyższej jest „kawałkiem papieru" i nie może on wskazywać, wpływać na produktywność (Clark, Martorell 2014: 282). Tym, co ma stanowić odzwierciedlenie realnej wartości dyplomu, są zarobki stanowiące zwrot poniesionych kosztów. Badacze w swojej pracy do opisania istotności związanej z ukończeniem studiów, wykorzystują między innymi teorię kapitału ludzkiego. Sugestie, jakie poruszyli w swoim artykule, stanowią o spadającej wartości dyplomów i o ich statystycznej nieistotności (uwzględniając różne zmienne) (Clark, Martorell 2014: 284). 
Istotnym elementem, który powinien zostać uwzględniony w kontekście utowarowienia edukacji wyższej i wartości dyplomów, jest zdefiniowane relacji między wartością użytkową i wymienną. Według teorii Marksa, za wartość użytkową uważa się: „zdolność towaru do zaspokojenia potrzeb” (Zagóra-Jonszta 2014: 14). Użytkowość towaru jest urzeczywistniana poprzez jego użycie czy spożycie, jest materialną formą bogactwa (Zagóra-Jonszta 2014: 14). Wartością wymienną jest z kolei „postać wartości wymiennej, wyrażającej stosunek ilościowy w jakim różnorodne wartości użytkowe zamieniały się nawzajem" (Zagóra-Jonszta 2014: 14). Między przedstawionymi wartościami występuje sprzeczność wiążąca się z pracą abstrakcyjną, której przykładem może być włożona energia w pracę czy siła umysłu, natomiast wartość użytkową określa włożona „praca konkretna” (Zagóra-Jonszta 2014: 14). Wartość dla Marksa była określana przy pomocy czasu (Zagóra-Jonszta 2014: 15). Ilość poświęconego czasu pracy decydowała o cenie towaru na rynku. Tym samym edukacja wyższa i zdobycie wykształcenia jest wartością wymienną. Długość czasu poświęcona na zdobycie dyplomu przekłada się na jego wartość w taki sposób, że czas definiuje pośrednio stopień wykształcenia. Wysoki stopień naukowy świadczy o ilości czasu, sile i energii poświęconej temu, by na rynku pracy stać się bardziej konkurencyjnym. Odtowarowione, elastyczne formy edukacji, jak kształcenie na odległość i e-learningi, nierzadko pozwalają na skrócenie czasu nauki przy jednoczesnym zdobywaniu kwalifikacji. Tym samym przez odtowarowienie umacniają się formy utowarowienia, gdzie ilość i czas nauki staje się rynkowym towarem (Baranowski 2017).

\section{EDUKACJA WYŻSZA I JEJ KOSZTY}

Studia na uczelniach wyższych publicznych w Polsce są darmowe. Stanowi o tym odpowiedni zapis w Konstytucji RP (AEGON 2013/2014: 4). Warto wspomnieć o tym, że chodzi o dzienny tryb studiów - studia zaoczne na uczelni państwowej są dodatkowo płatne. Pomimo tego chęć zdobycia wykształcenia wiąże się z ponoszeniem innych, dodatkowych kosztów. Trudno więc stwierdzić, że podjęcie dalszej edukacji na poziomie wyższym jest wolne od kosztów. Do nich natomiast można zaliczyć dodatkowe opłaty, które student powinien uiścić w ramach uniwersytetu - opłaty wpisowe, przystąpienie do egzaminów, wydanie odpowiednich dokumentów, jak na przykład certyfikaty językowe (AEGON 2013/2014: 4). Niektóre kierunki wymagają zakupu odpowiednich materiałów naukowych w postaci podręczników, jak i specjalistycznych ubrań (np. fartuchy czy okulary ochronne, szczególnie w przypadku kierunków medycznych). Uczelnie prywatne natomiast potocznie nazywane są „płatnymi studiami” z uwagi na czesne, jakie uiszcza student zapisujący się na taką uczelnię wyższą. Do kosztów studiowania dochodzą rachunki związane z zakwaterowaniem (wynajem mieszkania, nierzadko również akademik jest dodatkowo płatny). AEGON przedstawia szacowany koszt studiowania w Polsce na poszczególnych kierunkach w ciągu pięciu lat. Wydatki na zdobycie wykształcenia mieszczą się więc w przedziale od $20000 \mathrm{zl}$ do 60000 zł w zależności od kierunku studiów (2013/2014: 4). Za przykładowy koszt utrzymania w Polsce w raporcie zostaje uwzględniona kwota $2000 \mathrm{zł}$ miesięcznie, co daje 120000 zł poniesionych kosztów w skali pięciu lat (AEGON 2013/2014: 4). Stu- 
diowanie za granicą wiąże się ze wzrostem kosztów, na które składać się mogą czesne oraz koszty utrzymania. Jednak dla studentów z najlepszymi wynikami przeznaczone są programy stypendialne umożliwiające wyjazd za granicę, co pozwala obniżyć wydatki (AEGON 2013/2014: 5).

\section{REZYGNACJA Z PODJĘCIA STUDIÓW}

Podjęcie tematu utowarowienia edukacji czyni niezwykle istotnym pytanie o przyczyny rezygnacji ze studiów przez osoby młode, kończące szkołę średnią. Wydaje się również, że odpowiedź na nie może wyjaśnić, jak bardzo utowarowienie edukacji wpływa na podejmowanie decyzji potencjalnych kandydatów. Biorąc pod uwagę osoby, posiadające średnie wykształcenie w Polsce w roku 2016, na podstawie badań Eurostatu można wyróżnić kilka powodów, które stanowią jednocześnie przeszkodę w podjęciu wyższej edukacji.

Tabela 1. Przeszkody w uczestnictwie w kształceniu i szkoleniu według wykształcenia ponadgimnazjalnego i policealnego w Polsce w 2016 r.

\begin{tabular}{|l|l|}
\hline Procent osób & Przeszkoda/powód rezygnacji z dalszej edukacji \\
\hline $80,30 \%$ & Nie ma potrzeby (dalszego) kształcenia lub szkolenia \\
\hline $31,20 \%$ & Obowiązki rodzinne \\
\hline $19,80 \%$ & Harmonogram \\
\hline $15,70 \%$ & Koszt \\
\hline $14,60 \%$ & Inne powody osobiste \\
\hline $13,60 \%$ & Zdrowie lub wiek \\
\hline $8,80 \%$ & Brak wsparcia ze strony pracodawcy lub wsparcia usług publicznych \\
\hline $5,40 \%$ & Brak odpowiedniej działalności edukacyjnej lub szkoleniowej (oferta) \\
\hline $3,20 \%$ & Dystans \\
\hline $2,20 \%$ & Wymagania wstępne \\
\hline
\end{tabular}

Źródło: Opracowanie własne na podstawie danych Eurostat 2019c.

Na podstawie powyższej tabeli można zauważyć, że barierą, przez którą absolwenci nie chcą uczestniczyć w dalszej edukacji wyższej i innych szkoleniach jest to, że nie widzą potrzeby dalszego kształcenia. Może to wynikać z wielu alternatyw, z jakich mogą skorzystać młodzi ludzie ze średnim wykształceniem. Są to między innymi możliwości wczesnego podjęcia pracy, możliwy rozwój w ramach konkretnej branży, jak i perspektywa atrakcyjniejszych, w stosunku do kolejnych lat poświęconych edukacji, zarobków. Choć ocena, która ze ścieżek kariery dla młodych osób jest bardziej korzystna, jest kwestią subiektywną, to w kontekście niniejszej pracy można przyjąć, że w większości przypadków brak potrzeby edukacji związany jest z kwestiami pieniężnymi i czasem. Jest to przeszkoda wyraźnie wyróżniająca się na tle innych. Kolejną z przeszkód są obowiązki rodzinne - można spekulować, że są również związane z finansami rodziny i podejmowaniem przez młode osoby pracy w celu finansowego wspierania domowego budżetu. Sam koszt związany ze studiowaniem znalazł się dopiero 
na czwartym miejscu pod względem najczęściej wspominanych przeszkód. Może to oznaczać, że pomimo tego, że proces utowarowienia edukacji zmienił funkcjonowanie wielu uniwersytetów i pojawiło się coraz więcej kosztów związanych ze studiowaniem, to nie jest to najczęstszy powód, przez który osoby młode nie decydują się rozpocząć edukacji na poziomie wyższym. To, co wydaje się być optymistyczne, to fakt, że działalność edukacyjna i szkoleniowa wydaje się być odpowiednia, gdyż niewielki procent osób wskazał tę odpowiedź jako istotną barierę dla dalszego kształcenia.

\section{DEKOMODYFIKACJA - ALTERNATYWNE FORMY EDUKACJI WYŻSZEJ}

Alternatywną formą zdobywania wykształcenia może okazać się e-learning. Przyjmując definicję za Agatą Adamską, e-learningiem można nazwać: „różne formy kształcenia na odległość" (Adamska 2017: 84). W tym pojęciu mieszczą się zarówno całe kursy kształcenia, jak i narzędzia, które uzupełniają proces nauki (Adamska 2017: 84). Kursy on-line zyskują na popularności, ale warto jednak zwrócić uwagę na ich jakość. Najbardziej wartościowymi narzędziami e-learningu są te, które oferują uczelnie w ramach własnych programów studiów. Są przygotowywane z myślą o utrzymaniu standardów edukacyjnych, a uczestnik - student otrzymuje po jego ukończeniu odpowiedni certyfikat. E-learning nie jest w pełni sposobem odtowarowienia edukacji, ponieważ za część kursów nadal należy zapłacić, koszty jednak nie są tak wysokie jak w przypadku dziennego studiowania. Edustacja.pl (2019), portal oferujący szereg kursów internetowych, posiada sklep kursów on-line, co jedynie przyczynia się do postawienia tezy, że we współczesnych czasach także ta forma edukacji staje się utowarowiona. Skuteczność zdalnych kursów i jakości wykształcenia osoby z nich korzystających - poczynając od potrzeb rynku, aż po kompetencje samego e-ucznia. „Poradnik dla projektujących kursy e-learingowe” przedstawia sylwetkę ucznia korzystającego z kursów zdalnych. Powinien przejawiać chęć ciągłego rozwoju, odczuwać wewnętrzną motywację do nauki „na odległość”. Do cech idealnego ucznia autorki poradnika włączyły również posiadanie umiejętności pracy indywidualnej i grupowej, komunikacji między studentami oraz nauczycielami, a przede wszystkim zdolności e-ucznia do przyjmowania i tworzenia nowych rozwiązań oraz idei (Przybyła, Ratalewska 2012: 24). Liczy się także wytrwałość, konsekwencja, systematyczność (Przybyła, Ratalewska 2012: 22). Docelową grupą odbiorców kursów zdalnych stają się więc trzy grupy, które wyróżnia Krzysztof Dobosz. Są to osoby młode - dla których e-learning w większości jest rozszerzeniem dotychczasowego kursu, posiadają one wiedzę podstawową w danej dziedzinie i szukają jej dopełnienia. Osoby pracujące - traktujące kursy on-line jako sposób na rozwijanie zainteresowań, których nie mają związku z pracą zawodową i zarobkową. Ostatnią grupą, jaką wyróżnił Dobosz, są osoby bezrobotne. Dla tej grupy kursy zdalne umożliwiają zdobycie podstawowej wiedzy, niezbędnej do podjęcia pracy zarobkowej oraz zdobycia podstawowych umiejętności (Dobosz 2013: 20).

Wykorzystywanie kursów online w Polsce wciąż nie jest na tyle popularne, by całkowicie zastąpić tradycyjne formy zdobywania wykształcenia, szczególnie wyższego. Stanowią jedynie element uzupełniający dla trwającej lub ukończonej szkoły. Optymistyczne jest jednak to, że choć mała część osób z nich korzysta, to tendencja jest 
rosnąca. Dużo większym zainteresowaniem cieszą się różne, dowolne aktywności mające na celu podwyższenie poziomu własnej wiedzy. Również w przypadku takiej działalności internetowej tendencja jest rosnąca. Warto spojrzeć także na dane z podziałem na studentów i osoby bezrobotne, które według Dobosza powinny być szczególnie zainteresowane dodatkowymi formami edukacyjnymi mającymi na celu zwiększenie umiejętności i kompetencji.

Do niedawna mogłoby się wydawać, że bez praktycznych zajęć, fizycznego, aktywnego uczestnictwa, nie jest możliwe zdobycie wykształcenia z dziedzin takich jak medycyna. Zdobycie zawodu lekarza nadal nie jest w pełni możliwe za pośrednictwem internetu i płatnych kursów. Bez problemu natomiast udostępniane są kursy powiązane z medycyną - medycyna kosmetyczna, fizjoterapia i masaż (KursySzkolenia24 2019), kosmetologia, dietetyka (StudiaOnline 2019). Odszukanie pożądanego kursu nie wymaga od zainteresowanego dużego wysiłku ani poświęcenia dużej ilości czasu. Jest to jednak nieuniknione podczas poznawania poszczególnych ofert i jakości ich kształcenia. Jakość i rozpoznawalność podmiotu wystawiającego dyplom nierzadko jest wyznacznikiem wartości dyplomu na rynku pracy. Jak zostało już wspomniane, zakres kursów i kierunków oferowanych przez zróżnicowane podmioty jest bardzo szeroki. Nie można zdobyć zawodu lekarza bezpośrednio za pomocą nowych mediów, ale możliwe stało się zdobycie wykształcenia w kierunku pielęgniarstwa (StudiaOnline 2019). Praca pielęgniarek i pielęgniarzy zdobywa na znaczeniu, niejednokrotnie można usłyszeć, że wykonywane w tym zawodzie obowiązki są porównywalne do tych posiadanych przez lekarzy. Ukończenie studiów licencjackich online na kierunku pielęgniarstwo tożsame jest z uzyskaniem kwalifikacji zawodowych (StudiaOnline 2019).

To, co wzbudza wątpliwości dotyczy tego, kto korzysta z możliwości odtowarowionych ofert edukacyjnych. Zostało już wspomniane, że rodzaje kursów „na odległość”, za pomocą nowych technologii, najbardziej przydatne są trzem grupom jakie wyróżnił Dobosz. Wydaje się, że możliwość kształcenia przy niskim nakładzie finansowym jest doskonałym pomysłem, z którego powinny korzystać osoby o niższym kapitale ekonomicznym, czy też z rodzin niewystarczająco zamożnych. Są sposobem na rozwój, swojego rodzaju zachętą do podjęcia decyzji mających wpływ na przyszłość. W tej sytuacji pojawia się pewien paradoks - mimo możliwości oferowanych przez różne uniwersytety i instytucje, osoby posiadające mniejszy kapitał czy podstawowe wykształcenie nie będą w stanie wykorzystać tych ofert. Powodem tego jest to, że takie osoby w poczuciu niedostatku skupiają swoją uwagę na rozwiązywaniu problemów krótkotrwałych (Bergman 2018: 60). Zdaniem Bergmana sposobem na poradzenie sobie z ubóstwem jest zdobycie dyplomu ukończenia szkoły średniej, a w najlepszym wypadku - dyplomu świadczącego o ukończeniu uczelni wyższej (Bergman 2018: 59). Problem polega na tym, że osoby, które najchętniej powinny korzystać z możliwości różnych ofert edukacyjnych, nie robią tego, co niejako zmniejsza dostęp do przyszłych awansów na rynku pracy, szczególnie młodym osobom. Możliwość zdalnego kształcenia może więc przynieść odwrotne skutki - daje możliwość na zdobycie jeszcze większych umiejętności, większej wiedzy osobom, które już ją posiadają i są na znacznie lepszej pozycji. Przemoc symboliczna dotyka na tym poziomie już przyszłych kandydatów na studia, w tym młode osoby pragnące zdobyć wykształcenie, które pochodzą z rodzin 
posiadających mniejszy kapitał. Z uwagi na niewystarczające środki i gorszą edukację początkową nie potrafią w pełni skorzystać z możliwości, jakie oferuje kształcenie on-line. Utowarowiony system edukacji - szczególnie wyższej - przejawia przemoc symboliczną na każdym etapie, który składa się na kształcenie na uczelni. Rozpoczyna się już na pierwszych szczeblach edukacji i rozciąga aż po edukację wyższą. Joseph Stiglitz w książce „Cena nierówności” zwraca również uwagę na to, że polityka amerykańska, na którą składa się system szkolnictwa, sprawia, że szkolne wyniki, status uczniów, zarówno społeczny jak i ekonomiczny, w dużej mierze zależą od tego, jak zamożni są rodzice (Stiglitz 2015: 32). Jest to pierwszy moment, w którym uczniowie, przyszli kandydaci uczelni wyższych, doświadczają przemocy symbolicznej. Dodatkowo młodzi ludzie pragnący zdobyć wykształcenie niezbędne do walki z nierównościami doświadczają tego rodzaju przemocy począwszy od wyboru uczelni, poprzez cały proces edukacji, aż po zdobycie tytułu absolwenta i jego wejście na rynek pracy.

\section{KONSEKWENCJE I OCENA PROCESU UTOWAROWIENIA}

Przyglądając się analizie przeprowadzonej przez Marka Ziółkowskiego, można sformułować szereg konsekwencji, które są wynikiem urynkowienia instytucji uniwersytetu. Jednym z najbardziej widocznych następstw utowarowienia szkolnictwa wyższego jest paradoksalne zwiększanie zróżnicowania wśród społeczeństwa (Ziółkowski 2005: 39). Choć idea uniwersytetu w teorii gwarantuje bezpłatną możliwość studiowania (co zapewnia obecny system w Polsce) to w praktyce dostęp do uczelni wyższych jest zróżnicowany. Czynniki, które na nie wpływają, są zarówno społeczne jak i częściowo demograficzne. Łatwiejszy dostęp do edukacji wyższej posiada młodzież pochodząca z pewnych grup społecznych i pewnych miejscowości, pomimo że w założeniu jest to edukacja bezpłatna (Ziółkowski 2005: 39). Spada odsetek osób z rodzin nazwanych przez Marka Ziółkowskiego rodzinami wiejskimi, na co wpływ ma brak wystarczającej ilości kapitałów materialnych, społecznych oraz kulturowych (Ziółkowski 2005: 39). Dzieci, których rodzice są intelektualistami, są uprzywilejowane - posiadają pewną ilość każdego z rodzaju kapitałów, dzięki czemu w łatwiejszy sposób mogą rozpocząć kształcenie na wyższej uczelni. Kapitał materialny w oczywisty sposób się do tego przyczynia, bowiem za jego pomocą można pokryć wszelkie koszty związane ze studiowaniem na uczelni publicznej lub prywatnej. Kapitał kulturowy i społeczny posiadany przez uprzywilejowane dzieci przejawia się w bodźcach i wzorach przekazanych przez rodziców i znajomych (Ziółkowski 2005: 39). Jako przykład wykorzystania kapitału społecznego Marek Ziółkowski przytacza przyjmowanie osób z tak zwanego odwołania oraz listy z nazwiskami przyjętych. Mimo tego, że rośnie liczba osób z wyższym wykształceniem, to wciąż społeczeństwo polskie pozostaje zróżnicowane w zakresie wykształcenia (Ziółkowski 2005: 39). Taki wzrost można jednak uznać za pozytywne następstwo utowarowienia edukacji. Przyczyniły się do tego głównie nowopowstałe uczelnie prywatne, dzięki którym szkolnictwo wyższe rozwinęło się. Finansowane przez rodziny studentów i inicjatywy uczelnie prywatne, stały się bardziej atrakcyjne dla osób posiadających wcześniej wymienione rodzaje kapitałów. To, co sprawia, że uczelnie prywatne cieszą się popularnością, to przekonanie, że zainwesto- 
wane pieniądze przeobrażą się w późniejszy sukces. W opozycji do płatnych uczelni stoją publiczne, finansowane z budżetu państwa. Porównanie dwóch typów sprowadza się do postawienia tezy o słabości finansowej państwa (Ziółkowski 2005: 40). Stąd też utowarowienie w zakresie edukacji wyższej i uniwersytetów przyczynia się do zmian na tle politycznym i systemowym, a przynajmniej do przemyślenia zasad finansowania przez państwo w różnych dziedzinach, które dotykają społeczeństwo. Kolejną społeczną konsekwencją procesu komodyfikacji, która wprowadziła zmiany na uczelniach wyższych, jest powstanie napięć. Napięcia te według Marka Ziółkowskiego dotyczą funkcjonowania uczelni i kadry nauczającej (Ziółkowski 2005: 40). Są ściśle związane z przenikaniem się finansowania uczelni przez państwo z wolnorynkową sferą skoncentrowaną na sukcesie finansowym. Konsekwencją tego jest zauważalna zmiana w funkcjonowaniu różnego typów uniwersytetów (prywatnych czy publicznych), a co za tym idzie hierarchizacja i zmieniająca się atrakcyjność uczelni jako miejsca, w którym można podjąć pracę (Ziółkowski 2005: 40). Dochodzi do tego kolejne z następstw utowarowienia - nauczyciele akademiccy mogą być zatrudnieni na etat zarówno w sektorze publicznym jak i państwowym. Innym spośród zauważalnych następstw jest przewartościowanie tytułów naukowych i dyplomów świadczących o wykształceniu. Dla pracowników naukowych formalny tytuł stał się nie tylko czymś, co pozwala zdefiniować pozycję - jest też nierzadko wyznacznikiem wyższych zarobków (Ziółkowski 2005: 41). Tytuł naukowy stał się więc w dużej mierze sposobem na sukces finansowy obok sukcesów naukowych. Wartość dyplomu dla osób studiujących również uległa zmianie, o czym pisała już Marta Opiłowska, a co już zostało scharakteryzowane. Z uwagi na umasowienie i rosnącą liczbę osób kończących studia, zarówno na uczelniach prywatnych jak i publicznych, dyplom świadczący o wykształceniu traci na znaczeniu przez to, że stał się czymś pospolitym, niewyróżniającym wśród absolwentów i młodych osób na rynku pracy. Jego wartość jednak wciąż nie jest zerowa - dla wielu pracodawców i uczących się dyplom jest warunkiem koniecznym dla rozpoczęcia kariery i budowania przyszłości, co niejako też jest konsekwencją procesu utowarowienia i umasowienia w szkolnictwie wyższym. Zdaniem Marka Ziółkowskiego proces ten wpłynął również niekorzystnie na poziom edukacji w szkołach wyższych (Ziółkowski 2005: 41). Jest to jedna z konsekwencji komodyfikacji, która w szczególności jest najbardziej krzywdząca dla osób chcących podjąć studia na uczelni. Socjolog poznański podsumowuje: „Wykładana wiedza stała się towarem, ale jest to często towar nie najwyższej jakości" (Ziółkowski 2005: 41). Funkcją szkoły wyższej stało się dostarczenie dyplomu, który potwierdzi, że absolwent posiada wykształcenie, ale nie jest to jednoznaczne z posiadaniem odpowiedniej wiedzy, kompetencji czy umiejętności. Przypuszczalnie najbardziej wyraźną konsekwencją utowarowienia edukacji wyższej jest to, że związane z uniwersytetem obowiązki, wiedza, prace naukowe stały się swego rodzaju towarem. Marek Ziółkowski podaje za przykład wykład i referat, który oprócz uczelnianego obowiązku i „intelektualnej przyjemności” może być towarem, który posiada swoją „cenę”. Ta z kolei może być traktowana jako wymiana czy „sprzedawana za różne kwoty”, co nie musi być etyczne czy zgodne z prawem (Ziółkowski 2005: 42). Jedną spośród społecznych konsekwencji utowarowienia szkolnictwa wyższego może być również pojawienie się znacznie większej rywalizacji między studentami 
czy absolwentami, o czym w swoim artykule pisze Marta Opiłowska. Przemoc symboliczna, której doświadczają młodzi ludzie, niebezpośrednio zmuszani do szukania możliwości zdobycia wyjątkowych umiejętności i kompetencji, może mieć jednocześnie pozytywne następstwa. Rozwija to w pewnym stopniu kreatywność, umiejętność poszukiwania nowych rozwiązań, a podjęte dodatkowe kursy czy szkolenia mają już bezpośredni wpływ na samo wykształcenie młodego absolwenta uczelni wyższej. Patrząc na zjawisko utowarowienia edukacji wyższej, nietrudno dostrzec również negatywne następstwa tego procesu (Baranowski 2019). Studenci kończący masowo uczelnie wyższe postawieni są w bardzo niekorzystnej sytuacji na rynku pracy (Opiłowska 2009: 108). Trudności wiążą się ze zdobyciem dobrze płatnej pracy i często z koniecznością doszkolenia się w szczególnych dziedzinach. Innym następstwem związanym z komodyfikacją edukacji jest oprócz powstania wielu uczelni prywatnych - rozwój alternatywnych form nauczania. Platformy e-learningowe, uniwersytety i studiowanie on-line, krótkie szkolenia internetowe zyskują na popularności. Te, które są płatne, dają możliwość zdobycia wykształcenia osobom potrzebującym mobilności i elastyczności w nauce, czy osobom pracującym zawodowo, które nie mają możliwości fizycznego uczęszczania na zajęcia w gmachach uniwersytetów. Bezpłatny e-learning jest z kolei okazją do szybkiego zdobycia niektórych umiejętności czy zasobu wiedzy dla osób nieposiadających wystarczającego kapitału pieniężnego do podjęcia studiów na uczelniach publicznych.

Nie jest łatwo odpowiedzieć na pytanie, czy utowarowienie edukacji szczególnie na poziomie szkolnictwa wyższego jest jednoznacznie złe lub jednoznacznie dobre. Konsekwencje, jakie wynikają z tego procesu, mają zarówno swoje pozytywne jak i negatywne skutki dla osób młodych, kadr naukowych jak i rynku pracy. Wszystkie te podmioty podlegają następstwom pojawienia się mechanizmów rynkowych na uczelniach wyższych. Komodyfikacja w edukacji nie jest czymś dobrym dla osób z rodzin o niższych kapitałach ekonomicznych, społecznych czy kulturowych. Młodzież spotyka się z przemocą symboliczną, która przyczynia się do marginalizacji osób pochodzących ze wsi czy miejscowości znacząco oddalonych od ośrodków edukacyjnych. Jednocześnie powszechność wyższego wykształcenia w środowisku osób młodych sprawia, że zdobycie dyplomu jest współcześnie konieczne do podjęcia działań na rynku pracy. Przemoc symboliczna przenika przez proces utowarowienia na wyższych uczelniach, z czym muszą zmagać się współcześni studenci, wykorzystując alternatywne formy zdobywania wiedzy i umiejętności. Jest to proces budujący negatywne napięcie w społecznościach społecznych, przez który więzi, jakie dotychczas zawiązywały się pomiędzy studentami, nie są już tak wyraźne i tracą na swojej wartości, podobnie jak zdobywane kolejne dyplomy. Z innej perspektywy utowarowienie uniwersytetów stało się czynnikiem, który wraz z rozwojem nowych technologii zapoczątkował rozwój alternatywnych form nauki. Rozpowszechnienie platform e-learningowych daje możliwość doskonalenia i zdobywania wiedzy w elastyczny, często mobilny, sposób, co jest dużym atutem i co jest jednocześnie pożądane w nowoczesnym świecie. Urynkowienie jest impulsem skłaniającym do organizowania się studentów, tak jak w przypadku Uniwersytetu Zaangażowanego. Mimo nie zawsze pozytywnych wyników działań jakich podejmują się studenci, jest to wciąż rodzaj uczestnictwa zarówno w życiu studenc- 
kim, akademickim, jak również politycznym. Można przyjąć, że każda aktywność społeczna w ramach konkretnych idei jest społecznie ważna i przydatna. W przypadku edukacji zgromadzenia i protesty prowadzone przez Uniwersytet Zaangażowany są swego rodzaju „wentylami bezpieczeństwa”, które pozwalają zminimalizować napięcia pojawiające się wokół mechanizmów urynkowienia uniwersytetów, których doświadczają młodzi ludzie. Uniwersytet Powszechny, który nie został stworzony wyłącznie w odpowiedzi na postępujący proces komodyfikacji, sprawnie działa, niwelując jego negatywne skutki, głównie pomagając osobom wykluczonym podjęcie studiów na uczelniach wyższych publicznych. Biorąc pod uwagę wszystkie następstwa procesu utowarowienia edukacji, nie można jednoznacznie ocenić tego procesu. By to uczynić, należałoby skupić się na konkretnych grupach osób, których dotyczą konkretne zmiany i mechanizmy. Bez wątpienia ocena może dokonać się dopiero wtedy, gdy zostanie zbadany i uwzględniony bilans między pozytywnymi i negatywnymi skutkami procesu, jak również obecna sytuacja studentów, absolwentów czy pracowników naukowych na uczelniach wyższych.

\section{ZAKOŃCZENIE}

Celem artykułu było wyjaśnienie procesu utowarowienia z wyszczególnieniem edukacji wyższej oraz jego opis. Istotnym była także refleksja nad tym, jak sposób utowarowienia wpływa na młode osoby rozpoczynające, kończące lub planujące rozpocząć studia. Poruszone problemy składają się na cały proces komodyfikacji. Uwzględniono również jego daleko sięgające konsekwencje. Mając na uwadze problemy, z jakimi borykały się uniwersytety (na przykład niskie budżety czy generowanie własnych zysków), należy zwrócić uwagę, że proces komodyfikacji od początku był związany przede wszystkim z niewystarczającymi środkami uniwersytetów publicznych oraz z problemami finansowymi. Choć instytucje edukacyjne z założenia miały być miejscem, w którym wyrównywałyby się szanse uczniów, to jednak stało się inaczej. Szkoły i uniwersytety bardziej zaznaczały różnice między młodymi ludźmi, co jest jednym z przykładów wspomnianej wcześniej przemocy symbolicznej. Status majątkowy rodziny okazał się jednym z kluczowych kryteriów, jeśli chodzi o edukację młodych osób. Determinuje on bowiem szanse na zdobywanie wykształcenia na różnych płaszczyznach - począwszy od uniwersytetów prywatnych, które są opłacane przez rodziców, po dostęp do zdekomodyfikowanych instytucji edukacyjnych, jak Uniwersytet Powszechny czy szybko rozwijające się internetowe platformy edukacyjne. Rozwój odtowarowianych kanałów edukacji, to jest kształcenia na odległość za pomocą kursów on-line, jest przykładem skutków i swego rodzaju odpowiedzią na postępujący proces utowarowienia uniwersytetów. Zdaje się również, że stwierdzenie o bezpłatności nauki na uniwersytetach, przynajmniej w Polsce, jest mylące. Studenci niebezpośrednio zobowiązywani są do uiszczania wielu opłat, które okazują się być niezbędne do kontynowania nauki. Inną z konsekwencji, dla których młodzi ludzie rezygnują z podjęcia studiów, co jest związane z ich utowarowieniem, jest brak potrzeby dalszego kształcenia (Shner 2018). Dodatkowe koszty związane z edukacją sprawiły, że młode osoby szukały i być może znalazły sposób na to, by funkcjonować na rynku pracy bez wyższego wykształcenia, które 
w obliczu masowej edukacji traci na swojej wartości, co jest kolejną z konsekwencji opisywanego procesu.

Trudno jednoznacznie stwierdzić, kto zyskuje na utowarowieniu w edukacji, a komu powinno zależeć na odwrotnym procesie. Zyski płynące z występowania tego procesu na uczelniach przejawiają się w postaci zróżnicowania społeczeństwa pod względem wykształcenia. Absolwentom uczelni wyższych taka sytuacja daje możliwość konkurowania na rynku pracy. Z drugiej strony to właśnie przyszłym studentom, których kapitał jest niewystarczający by rozpocząć studia, najbardziej powinno zależeć na tym, by edukacja wyższa stawała się bardziej zdekomodyfikowana. Na komodyfikacji zyskują również same uczelnie, a ich zysk jest mierzalny - są to między innymi dochody z prowadzenia uniwersytetu, prowadzenia badań naukowych i wpłat studentów. Należy również pamiętać, że portale internetowe oferują materiały edukacyjne, możliwości zdobycia wykształcenia w sposób mobilny i bez większych kosztów. Pozornie bezpłatne platformy także generują zyski, tym samym właściciele platform zyskują na ich prowadzeniu. W zależności od potrzeb współczesnej edukacji oraz studentów, a także od sytuacji demograficznej czy rynkowej, podmiot, któremu miałoby najbardziej zależeć na odtowarowieniu edukacji, będzie się zmieniał.

Choć nie zawsze motywacja jest odpowiednia, by rozpoczynać nowe etapy nauczania, to w społeczeństwie informacyjnym edukacja jest czymś, co autorzy Witold Kołodziejczyk i Marcin Polak nazywają „najważniejszym obszarem aktywności życiowej” (Kołodziejczyk, Polak 2011: 57). Trudno więc zgodzić się z twierdzeniem, że edukacja jest nieistotna. Uniwersytetom i szkołom trudniej jest zareagować i przystosować do wspomnianej zmieniającej się rzeczywistości i społeczeństwa informacyjnego. Edukacja jest jednak ważnym elementem, ponieważ dzięki niej ludzie przystosowują się do życia i pracy w realiach, jakie stawia przed nimi świat (Kołodziejczyk, Polak 2011: 59).

Istotnym będzie podsumowanie, co faktycznie oznacza, że edukacja na poziomie wyższym jest utowarowiona. Biorąc pod uwagę wcześniejszą analizę tego procesu, można stwierdzić, że utowarowienie edukacji oznacza, że w dużej części jest ona uzależniona od procesów rynkowych i kapitału ekonomicznego, zarówno instytucji jak i osób uczących się. Utowarowienie przejawia się we wszelkich opłatach niezbędnych do rozpoczęcia czy kontunuowania nauki na uczelniach wyższych. Na proces ten składają się również inne koszty z nią związane, takie jak obowiązkowe materiały czy pomoce naukowe. Komodyfikacja w edukacji to również pogłębianie różnic między studentami, którzy z uwagi na zasoby pieniężne jakie posiadają i jakie posiada ich rodzina, nie mogą w równym stopniu korzystać ze wszystkiego, co oferują uniwersytety. Tym samym utowarowienie na uniwersytetach to również przemoc symboliczna, która nie jest od razu zauważalna. Trudno jest wyznaczyć wymierną granicę utowarowienia w edukacji wyższej z uwagi na złożoność tego procesu i wielość elementów, jakie się na niego składają. Granice te jednak istnieją i są zależne od indywidualnego położenia jednostki w strukturze społecznej. 


\section{BIBLIOGRAFIA}

Adamska, Agata. 2017. “Efektywność e-nauczania z perspektywy szkoły wyższej”. Edukacja Ekonomistów i Menedżerów: Problemy, Innowacje, Projekty 2(44): 83-95.

AEGON. 2013/2014 Koszty studiowania w Polsce i za granica. https://www.aegon.pl/ siteassets/media/raporty/raport-kosztow-studiowania-w-polsce-i-za-granic aegon.pdf. Dostęp 28.03.2019.

Baranowski, Mariusz. 2017. "Education in Times of Uncertainty. Uncertainty in Education. A Critical Approach.” Ss. 63-72 w Symbolic Violence in Socio-Educational Context. A post-Colonial Critique, pod red. A. Odrowąż-Coates, S. Goswami. Warszawa: Wydawnictwo Akademii Pedagogiki Specjalnej, s. 63-72.

Baranowski, Mariusz. 2019. "The Struggle for Social Welfare: Towards An Emerging Welfare Sociology.” Society Register 3(2): 7-19. https://doi.org/10.14746/ sr.2019.3.2.01

Bergman, Rutger. 2018. Utopia dla realistów. Tłum. Sławomir Paruszewski. Warszawa: Czarna Owca.

Bourdieu, Pierre i Jean-Claude Passeron. 1990. Reprodukcja. Elementy teorii systemu nauczania. Tłum. Elżbieta Neyman. Warszawa: PWN.

Bourdieu, Pierre i Loic Wacquant. J. D. 2001. Zaproszenie do socjologii refleksyjnej. Tłum. Anna Sawisz. Warszawa: Oficyna Naukowa.

Clark, Damon i Paco Martorell. 2014. “The Signaling Value of a High School Diploma .” Journal of Political Economy 122(2): 282-318.

Dobosz, Krzysztof. 2013. E-edukacja. Obserwatorium ICT.

Edustacja. 2019. Dostęp online: http://edustacja.pl/ Dostęp 24.02.2019.

Eurostat. 2012. The European Higher Education Area in 2012: Bologna Process Implementation Report. https://ec.europa.eu/eurostat/documents/3217494/5735241/EC30-12-534-EN.PDF/ffb0b7c9-bf5e-4696-984f-a05b135fe5a3. Dostęp 28.03.2019.

Eurostat. 2019c. Obstacles to participation in education and training by educational attainment level. https://ec.europa.eu/eurostat/web/products-datasets/-/trng_ aes_178. Dostęp 05.04.2019.

Główny Urząd Statystyczny. 2017. Szkoły wyższe $i$ ich finanse w 2016 r. Warszawa. https://stat.gov.pl/obszary-tematyczne/edukacja/edukacja/szkoly-wyzsze-iich-finanse-w-2016-r-,2,13.html. Dostęp 28.03.2019.

Główny Urząd Statystyczny. 2019. Ludność. Stan i struktura oraz ruch naturalny w przekroju terytorialnym w 2018 r. Stan w dniu 31 XII. Warszawa. https://stat.gov.pl/ obszary-tematyczne/ludnosc/ludnosc/ludnosc-stan-i-struktura-oraz-ruch-naturalny-w-przekroju-terytorialnym-w-2018-r-stan-w-dniu-31-xii,6,25.html. Dostęp 15.05.2019.

Główny Urząd Statystyczny. Bank Danych Lokalnych. 2019. https://bdl.stat.gov.pl/ BDLS/dane/podgrup/wymiary. Dostęp 05.04.2019

Kołodziejczyk, Witold i Marcin Polak. 2011. Jak będzie zmieniać się edukacja. Wyzwania dla polskiej szkoły i ucznia. Warszawa: Instytut Obywatelski. http://www.instytutobywatelski.pl/wp-content/uploads/2011/11/edukacja_kolodziejczyk-polak_internet.pdf. Dostęp 16.05.2019. 
KursySzkolenia24. 2019. Najnowsza oferta edukacyjna 2019. https://www.kursyszkolenia24.pl/oferta_kursow_szkolen.php._Dostęp 05.03.2019.

Opiłowska, Marta. 2009. “Współcześni studenci jako stratedzy własnej kariery zawodowej: (w świetle teorii gier i kredencjalizmu”. Teraźniejszość - Człowiek - Edukacja: kwartalnik myśli społeczno-pedagogicznej 4 (48): 107-126.

Shner, Moshe. 2018. “The Idea and Practicalities of 'Nature' in Janusz Korczak Philosophy.” Society Register 2(2): 85-106. https://doi.org/10.14746/sr.2018.2.2.05

Stiglitz, Joseph E. 2015. Cena nierówności. W jaki sposób dzisiejsze podziały społeczne zagrażają naszej przyszłości? Warszawa: Wydawnictwo Krytyki Politycznej.

StudiaOnline. 2019. Studia online - kierunki I i II stopnia. https://www.studiaonline. info/s/3639/75152-Kierunki-studiow-online.htm?kg=17. Dostęp 05.03.2019.

Suchocka, Agnieszka. 2011. "Przemoc symboliczna jako element ukrytego programu kształcenia polskiej szkoły”. Zeszyty naukowe Akademii Marynarki wojennej LII 4 (187): 293-302. http://www.amw1.iq.pl/library/File/ZeszytyNaukowe/2011/ ZN_4_2011/Suchocka\%20A.pdf. Dostęp 28.03.2019.

Zagóra-Jonszta, Urszula. 2014. "Rozważania wokół wartości - od Marksa do czasów współczesnych”. Studia Ekonomiczne 173: 13-21. http://cejsh.icm.edu.pl/cejsh/element/bwmeta1.element.desklight-cf20afd6-618c-49eb-9f9f-3daf0e73bc27?q=dd4d5d4e-adba-4883-9369-b90737ad75b6\$1\&qt=IN_PAGE Dostęp 14.06.2019.

\title{
Analysis of the process of commodification of education with speci- fication of higher education
}

\begin{abstract}
The analysis of the process of commodification of education with the specification of higher education was the subject of the bachelor's thesis, which the purpose was to explain this phenomenon and its detailed description. The subject restricted the scope of main problem to higher education because of formal limitations of bachelor's thesis and the volume of issues. The main research problem was to find the answer to the question to what extent and how the commodification of education affects the chances of educating to young people. Characteristics of the phenomenon took into account the problems concerning the consequences of the commodification process and its elements. The following chapters of bachelor's thesis contained an explanation of the significance of the phenomenon, key concepts and the context of the appearance of commodification in the area of education. It was also important to pay attention to the reverse process which is decommodification. There were specify the forms which take decommodification of education and its advantages and disadvantages. The analysis also included the consequences of the commodification and decommodification process, which contained among others the lowering of the value of diplomas. To explain the purpose and research problems of bachelor's thesis, a
\end{abstract}


secondary data analysis was use and include literature, scientific papers and reports, including the Polish Central Statistical Office and Eurostat. The analysis contained reports and data on Poland as well as other European countries, which made it possible to compare important aspects of commodification in education between countries and outline the situation of universities in Europe. Based on the analysis of data, the most important consequences of the commodification process in the higher education that were signalize included: broadening the diversity among the population, the growing number of people with higher education, the emergence of alternative forms that enable the acquisition tertiary, converting academic knowledge into the knowledge taking the form of the commodity. The process of commodification of higher education is undoubtedly noticeable at universities, which has been documented in bachelor's thesis by describing its individual components and consequences.

KEYWORDS: commodification, higher education, decommodification, symbolic violence 
